\title{
Enfekte ve/veya kemik defektli psödoartrozlarda kullanılan özel teknikler
}

\author{
Special surgical techniques in infected and/or defective pseudoarthrosis \\ Cengiz Şen ${ }^{1}$, Yavuz Sağlam² \\ ${ }^{1}$ İstanbul Üniversitesi, İstanbul Tıp Fakültesi, Ortopedi ve Travmatoloji Anabilim Dalı, İstanbul \\ ${ }^{2}$ Biruni Üniversitesi Tıp Fakültesi, Ortopedi ve Travmatoloji Anabilim Dalı, İstanbul
}

\begin{abstract}
Kemik kayıplarında yeniden kaynama sağlanması ve uzuv fonksiyonlarının geri kazanılması, ortopedik cerrahinin zor sahalarından birisidir. Cerrahi strateji, kaybın nedeni ve hastanın beklentileri göz önünde tutularak belirlenmelidir. Eşlik eden hastalıklar (diyabet, kronik böbrek yetmezliği, vb.), sigara bağımlılığı, bağışıklık sisteminin durumu ve kırık bölgedeki enfeksiyonun varlığı her aşamada değerlendirilmelidir. Biz bu bölümde, kemik kayıplarına yaklaşımdan ve bu kayıpların rekonstrüksiyonda en sık kullanılan yöntemlerden (Masquelet yöntemi, segment kaydırılması, akut kısaltma ve kemiğin sağlıklı bir yerinden uzatma ile kombine tekniklerden) bahsedeceğiz.
\end{abstract}

Anahtar sözcükler: kemik kaybı; kaynamama; segment kaydırma; akut kısaltma
Reconstruction of the bone loss and restoration of limb function is one of the difficult fields of orthopedic surgery. Surgical strategy should be determined by considering the cause of loss and the expectations of the patient. Associated conditions (diabetes, chronic renal failure, etc.), cigarette addiction, the state of the immune system, and the presence of infection in the fractured area should be assessed at each stage. In this section we will talk about the approach to bone loss, and the procedures most commonly used for reconstruction (Masquelet method, bone transport, acute shortening and re-lengthening from the healthy segment, and combined techniques).

Key words: bone loss; pseudoarthrosis; bone transport; acute shortening emik kayıplarının tedavisi ve yeniden kaynama sağlanması, ortopedik cerrahinin zor sahalarından birisidir. Kayıp miktarı arttıkça, hastanın geçirmesi gereken cerrahi sayısı ve bununla doğru orantılı olarak komplikasyonlar da artmaktadır. Defekt miktarı $8 \mathrm{~cm}$ 'nin üzerinde ise bu durum mega kemik defekti olarak tanımlanmaktadır. Cerrahi strateji, kaybın nedeni ve hastanın beklentileri göz önünde tutularak belirlenmelidir. Uzuv uzunluğunun ve fonksiyonlarının geri kazanımı sırasında, öncelikle hastanın genel durumu, eşlik eden hastalıkları (diyabet, kronik böbrek yetmezliği vb.), sigara bağımlılığı, bağışıklık sisteminin durumu ve kırık bölgedeki enfeksiyonun kontrol altına alınması, başlanacak olan tedavinin ilk basamağını oluşturmalıdır. Kemik kaybı olan bölgedeki kaynamanın ve ekstremite uzunluğunun temini ise ikinci basamak tedavi hedefi olmalıdır. Mega kemik kayıplarında en sık nedenler, kemik tümörü rezeksiyonları, kronik osteomiyelite bağlı segment rezeksiyonları veya travmaya bağlı kemik kayıplarıdır. Biz bu bölümde travma sonrası oluşan kemik kayıplarına yaklaşımdan ve bu kayıpların rekonstrüksiyon yöntemlerinden bahsedeceğiz. ${ }^{[1-3]}$

\section{ETIYOPATOGENEZ VE SINIFLAMA}

Defektin olduğu bölge, psödoartroz (kaynamama) sahası olarak değerlendirilmeli ve bu şekilde hareket edilmelidir. Tanım olarak, travmadan itibaren dokuz ay geçmiş ve son üç aydaki kontrollerde kaynamada ilerleme gözlenmeyen olgularlar kaynamama olarak tanımlanmaktadır. Kaynamamanın sistemik ve bölgesel (lokal) nedenleri vardır. Sistemik nedenler arasında sigara kullanımı, ileri yaş ( $>65$ yaş), malnütrisyon, anemi, diyabet ve kronik böbrek yetmezliği gibi eşlik eden hastalıklar, hormonal bozukluklar ve kortizon türevi ilaç kullanımı sayılabilir. Lokal nedenler arasında ise; açık, yüksek enerjili, segmental kırıklar, kırık bölge ve kırık hatları arasındaki doku interpozsiyonu, tespit yetersizliği, açık redüksiyon ile periosteal dolaşımın etkilenmesi,

- Illetişim adresi: Prof. Dr. Cengiz Şen, İstanbul Üniversitesi, İstanbul Tıp Fakültesi, Ortopedi ve Travmatoloji Anabilim Dalı, İstanbul Tel: 0532 - 2456365 e-posta: senc64@gmail.com

- Geliș tarihi: 1 Kasım 2017 Kabul tarihi: 1 Kasım 2017 
kemik ve yumuşak doku kaybı, ateşli silah yaralanmasına bağlı kemik ucu nekrozları, damar ve sinir yaralanmaları ve tekrarlayan cerrahi girişimler sayılabilir. ${ }^{[1,2,4,5]}$ Kaynamama tipleri şu şekilde sınıflandırılır:

\section{Weber-Cech Kaynamama Sınıflaması ${ }^{[6]}$}

- Enfekte kaynamama: Kaynamanın gerçekleşmediği sahadaki ana problemin enfeksiyon olduğu tiptir.

- Hipertrofik kaynamama: Uygun olmayan tespit materyali seçimi veya yetersiz tespit süresine bağlı, ön planda mekanik yetersizlik ile seyreden, biyolojik problemin olmadığı tiptir.

- Atrofik kaynamama: Biyolojik yetmezliği ön planda olduğu, aynı zamanda tespit yetersizliği de olan kaynamama tipidir.

- Oligotrofik kaynamama: Neden genellikle yetersiz redüksiyon ve kırık uçlarının birbirinden uzak olmasıdır.

\section{Paley Kaynamama Sınıflaması ${ }^{[7]}$}

- Tip A (<1 cm kemik kaybı varlığı)

- A1, mobil*

- A2, mobil değil*

- A2-1, deformite yok

- A2-2, fikse deformite mevcut

- Tip B ( >1 cm kemik kaybı varlığı)

- B1, kemik defekti mevcut, kısalık yok

- B2, kısalık var, kemik defekti yok

- B3, kemik defekti ve kısalık mevcut

*Kaynamama sahasındaki mobilite miktarı: Mobil değil $\left(<5^{\circ}\right.$ hareket), kısmen mobil (5-20 ${ }^{\circ}$ hareket), mobil (>20 ${ }^{\circ}$ hareket)

\section{FiZiK MUAYENE VE GÖRÜNTÜLEME}

Kemik kaybının olduğu bölgedeki cilt ve yumuşak doku kayıpları öncelikli olarak dikkate alınmalıdır. Yumuşak doku kaybının derecesine bağlı olarak hastanın kalıcı cerrahi tedavisinin zamanlaması belirlenmeli, gerekirse yumuşak doku rekonstrüksiyonu ile beraber yapılmalıdır. ${ }^{[8]}$

Bu yaralanmalar sırasında oluşmuş olabilecek çevre damar yapılardaki hasarlar dikkatlice gözden geçirilmeli, nabızlar ve kapiller dolum muayene edilmeli, periferik sinir muayenesi ayrıntılı olarak yapılmalıdır.

Ekstremitenin dizilimi, deformite ve enfeksiyonun varlığı, komşu eklemlerdeki hareket kayıpları ve kısalık miktarı dikkate alınarak tedavi planlaması yapılmalıdır.
Planlama sırasında öncelikli olarak gerçek boyut, kaybın olduğu kemiğin bir üst ve bir alt eklemini içine alacak şekilde tam AP (antero-posterior) ve tam yan (lateral) grafiler çekilmelidir. Bunun yanında, kısalık miktarı telafi edilerek, pelvisin yere paralel hale getirildiği, patellaların tam olarak önde olduğu, ayakta kalçalar ve ayak bilekleri görünecek şekilde bacak boy grafileri (ortoröntgenografi) çekilmelidir.

Eğer hastada osteomiyelit şüphesi mevcut ise manyetik rezonans (MR) görüntüleme yapılmalı ve eksize edilecek kemik miktarına MR görüntülerine bakılarak karar verilmelidir.

Özellikle daha önce ameliyat geçirmiş hastalarda, damarsal anatominin görüntülenmesi gerekliliğinde Doppler ultrasonografi (Doppler USG), BT (bilgisayarlı tomografi) anjiyografi veya konvansiyonel anjiyografi yapılabilir. Özellikle yumuşak dokunun rotasyonel veya serbest flepler ile rekonstrüksiyonu düşünülen hastalarda, damarsal yapıların görüntülenmesi daha fazla önem arz etmektedir. ${ }^{[1,8]}$

\section{CERRAHI HAZIRLIK}

Kemik kayıplarındaki cerrahi uygulamalar, nispeten az uygulanan ve ciddi tecrübe gerektiren işlemlerdir. Cerrahın daha önceden bu tip girişimleri uygulamış olması, ekstremitenin cerrahi anatomisini ve yaklaşımlarını iyi bilmesi gerekmektedir. Bölgedeki damar ve sinir yapılarının disseksiyonu ve eksternal fiksatör uygulamaları konusunda yeterli tecrübeye sahip olması gereklidir. Cerrahi öncesinde boyama ve örtme esnasında, iliak kanatlar açık olacak şekilde örtülmeli ve bu bölgeden greft alınabileceği hasta ve yakınları ile ameliyat öncesinde paylaşılmalıdır. İşlemin uygulanacağı masanın, skopi kullanımına izin veren, radyolusen bir masa olmasına dikkat edilmelidir.

\section{CERRAHI işLEMLER}

Kemik defektlerinin tedavisi için literatürde birçok yöntem tanımlanmıştır. Masquelet'in tanımladığı iki aşamalı rekonstrüksiyon ${ }^{[9]}$, segment kaydırma, akut kısaltma ve sağlıklı bir yerden uzatma gibi günümüzde daha çok tercih edilen yöntemlerden, ilerleyen bölümlerde ayrıntılı olarak bahsedilecektir. Damarlı veya damarsız fibula transferi, debridman sonrası damarlı kas transferi, plak-vida ile tespit ve grefonaj, intramedüller çivi ile tespit ve grefonaj, intramedüller çivi + kafes ile tespit ve grefonaj da nadiren de olsa uygulanabilen tedavi yöntemleridir. Nadir uygulanan bu tedavi yöntemlerinin dezavantajları arasında; kaynamama ve enfeksiyon oranlarındaki yükseklik, ekstremite diziliminin ve uzunluğunun sağlanmasındaki zorluklar, uzun 
tedavi süreleri, devam eden enfeksiyonlar sonucu malign dönüşümün olabilmesi ve yüksek tedavi maliyetleri sayılabilir. ${ }^{[1-3,7,10-14]}$

\section{Masquelet Yöntemi}

Masquelet'in 1986 'da kendi adı ile tanımladığı kemik kayıplarının tedavisinde kullanılan bir yöntemdir. Tekniğin orijinal tanımında $5 \mathrm{~cm}$ ile $25 \mathrm{~cm}$ arasındaki kayıplarda başarı ile uygulanabildiği belirtilmektedir. Yöntem iki aşamalı bir cerrahiden oluşmaktadır. ilk aşamada psödoartroz sahası rezeke edilmekte, radikal debridman yapıldıktan sonra, kemikte oluşan defektif saha kemik çimentosu (polimetilmetakrilatPMMA) ile doldurulmaktadır. Yumuşak doku kapanma problemi mevcut ise, serbest veya rotasyonel flepler ile bölge rekonstrükte edilmelidir. Sekiz hafta kadar sonra bölge yeniden açılarak, kemik çimentosunun üzerinde oluşmuş olan membran bistüri ile düzgün bir şekilde açılmakta, çimento tamamen temizlenip, oluşmuş olan defektli saha kişinin kendisinden (otogreft) ve/veya kadavradan alınan (allogreft) kansellöz kemik grefti ile doldurulmaktadır. Bu süreçte kemik stabilitesi öncelikle bir eksternal fiksatör ile sağlanmakta, ikinci aşama sonrasında ya eksternal tespite devam edilmekte, ya da fiksatör çıkarılıp plakvida veya intramedüller çivi ile tespit sağlanmaktadır. $\mathrm{Bu}$ sayede damar anastomozu gerektiren tip kemik nakilleri (damarlı fibula) ihtiyacı azalmıştır. ${ }^{[9]}$

ilk aşamada uygulanan çimento ile, bacak boyunun kısalmaması ve stabilite sağlanmaktadır. Ardından oluşan membran ise, greftlerin dağılmasını engellemekte ve yine immün sistem ile teması azaltıp rezorpsiyonun önüne geçmektedir. Gerber ve ark. ${ }^{[15]}$ yaptıkları çalışmada, oluşan membranın kalitesinin kaynamayı ve stabiliteyi doğrudan etkilediğini göstermişlerdir. Yapılan çalışmalarda, membranın vasküler endotelyal büyüme faktörü (VEGF) ve transforming büyüme faktör beta (TGFB) salınımı yaptığı gösterilmiştir.

Tekniğin uygulanması için, ortamın enfeksiyondan tamamen arındırılmış olması gerekmektedir. Komplikasyon oranı az olmasına karşın, yöntemin uygulandığı ekstremiteye uzun süreli yük verilmemesi ve ciddi miktarlarda kemik greftine ihtiyaç duyulması, yöntemin dezavantajları arasında sayılabilmektedir.

\section{Segment Kaydırılması (SK), (Bone Transport)}

Bu yöntem ile kemik kaybının telafisi sağlanabilmekte ve var olan deformite düzeltilebilmektedir. Femur için tek planlı (mono-planar) veya çok planlı (multi-planar, llizarov tipi, sirküler) eksternal fiksatörlerin kullanımı hastanın ve ekstremitenin klinik özelliklerine göre seçilebilecekken, tibia için hemen her zaman Ilizarov tipi sirküler eksternal fiksatörler tercih edilmektedir. Oluşturulacak çerçevede (frame), proksimal ve distali tespit eden halkalar dışında, segmentin kayması için planlanacak orta kısımda bir adet halka olmalıdır. Kemiğin sağlam bir yerinden yapılacak osteotomi sonrası, çerçeve üzerindeki rodların yardımı ile kemik segmenti uygun rotada, kaybın olduğu bölümü kapatmak için kaydırılır. Günlük segment kaydırma miktarı, distraksiyon osteogenezisi kuralları uygulanarak günde $1 \mathrm{~mm}(0,25 \mathrm{~mm} \times 4$ kez) olarak yapılmalıdır. Gereklilik halinde, kaydırma miktarı yeni oluşturulacak kemiğin (rejenerat) kalitesini arttırmak adına daha yavaş da planlanabilir $(0,25$ $\mathrm{mm} \times 3 \mathrm{kez}=$ günde $0,75 \mathrm{~mm})$. Bu yöntem ile kısalık giderilebilir, uygun dizilim sağlanabilir.

Tedavi süresinin nispeten uzun olması, komplikasyon oranları ve hastanede kalış sürelerinin yüksek olması, yüksek maliyet ve tecrübeli cerrahi ekip gereksinimi, yöntemin dezavantajları arasında sayılabilir.

Kemik kaybının olduğu saha ameliyat öncesinde röntgen görüntülemeleri ile belirlenir ve kaydırılacak kemik saha seçilerek ameliyat öncesinde eksternal fiksatör çerçevesi uygun şekilde oluşturulur. Kemiğin kaydırılması için serklaj ve kablo gibi internal kaydırma yöntemleri veya direkt rodlar yardımı ile halka üzerinden eksternal kaydırma yöntemleri tercih edilebilir. Biz, daha kolay ve konforlu olduğu için, eksternal yöntem ile segmentin kaydırılmasını tercih etmekteyiz. Öncelikle osteotominin yapılacağı yer belirlenerek, gigli teli uygun yöntemle geçirilir ve halka proksimal ve distal referans telleri kullanılarak kemiğe adapte edilir. Sekestrum halindeki kronik osteomiyelit veya aktif enfeksiyon olan olgularda segment rezeksiyonu yapılır. Sonrasında, tüm halkalar ilgili segmentlere K-telleri ve Şanz vidaları ile tespit edilip stabil bir çerçeve elde edilir. Fibulanın proksimal ve distal segmentler ile stabil bir şekilde hareketini temin etmek için, zeytinli (olivli-stoplu) teller ile halkaya adaptasyon sağlanır. Ardından, osteotomi tamamlanarak segmentin hareketi skopi ile kontrol edilir. Tüm bu işlemlerin ardından, sistem kontrol edilerek ameliyata son verilir. Segmentin kayması sırasında cilt irritasyonu (rahatsızlığı) ve buna bağlı ağrı olabilir. Segmentin hareketi sonrasında karşı karşıya gelen kemiklerin (docking site) kaynaması için genellikle kemik grefonajı yapılmaktadır. ${ }^{[11,16,17]}$

Cerrahi işlem sonrasında, segmentin kaydırılması işlemine 7-10 gün kadar sonra başlanmalıdır. Bu süreçte hasta, çevre eklemleri hareketli tutmak ve kontraktürleri önlemek adına egzersiz yapmalı, geçici osteoporozun önüne geçmek için ise uygun şekilde yürümelidir (Şekil 1). 

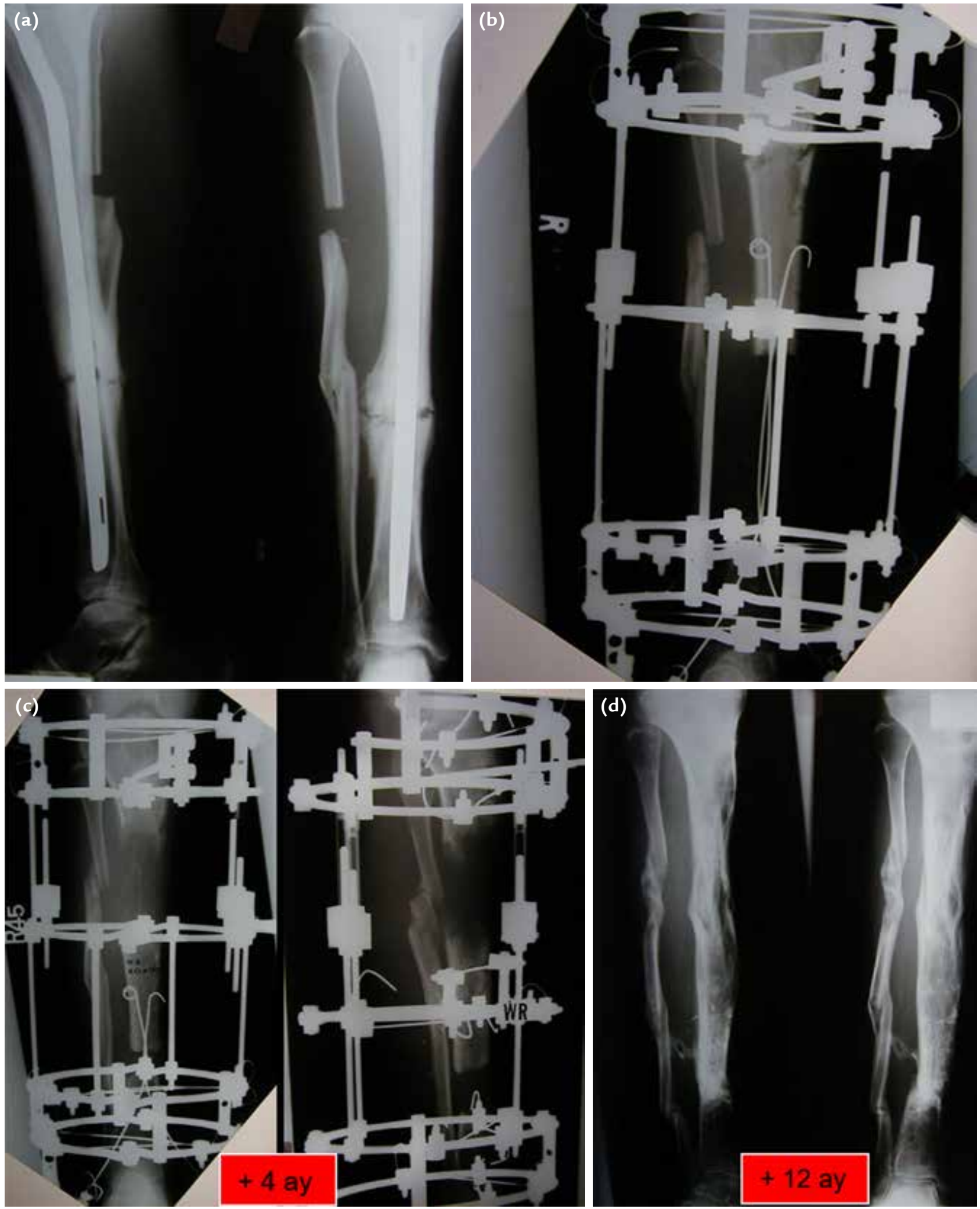

Şekil 1. a-d. Araç içi trafik kazası sonrasında açık sağ tibia kırığı olan ve intramedüller çivi ile tespiti yapılan, 48 yaşındaki kadın hastada bir yılın sonunda kaynama elde edilememiş (a). Kaynamayan ve enfeksiyon tespit edilen bölge sağlam kemiğe kadar rezeke edilmiş, internal kaydırma yöntemi ile segment kaydırılması planlanmış (b). Segmentin uygun şekilde hareket ettiği 4 . ay röntgeninde görülmekte (c). Birinci yılın sonunda kaynama elde edilmiş (d). 


\section{Akut Kısaltma ve Kemiğin Sağlıklı Bir Yerinden Uzatma (AKU)}

Segment kaydırma yöntemine benzer şekilde, bu yöntemde de eksternal fiksatör yardımı ile kemik kaybının telafisi ve var olan deformitenin düzeltilmesi sağlanabilmektedir. Bu yöntemin uygulanması ile tedavi süresi nispeten kısalmakta, komplikasyon oranları da buna paralel olarak azalmaktadır. Tedavi maliyetleri segment kaydırma tekniğine oranla daha düşüktür. Enfekte saha akut olarak rezeke edilip kısaltılacağı için, serbest flep gibi komplike bir yumuşak doku rekonstrüksiyonuna genellikle ihtiyaç olmamaktadır. Femur için sıklıkla kombine (intramedüller çivi ile birlikte mono-lateral fiksatör) veya çok planlı (Ilizarov tipi sirküler) eksternal fiksatörlerin kullanımı hastanın ve ekstremitenin klinik özelliklerine göre seçilebilecekken, tibia için hemen her zaman Ilizarov tipi sirküler eksternal fiksatörler tercih edilmektedir. Çerçevenin hazırlanması sırasında, kayıp bölgesinde akut kompesyon yapılacağı ve bu bölgede stabil tespite ihtiyaç duyulacağı öngörülerek, defekt hattının 4-5 cm proksimaline bir halka ve distaline bir halka konulmalıdır. Tibia distalinde, eklem yüzeyine $4 \mathrm{~cm}$ 'den az bir bölge kalır ise, ayak halkası da kullanılarak stabilite arttırılmalıdır.

Yine, uzatmanın yapılacağı bölge için uzatma rodları çerçeve üzerine önceden konulmalıdır. Akut olarak kapatılan defekt bölgesinde, ameliyat sonrasında kompresyona tedricen devam edilebilir. Kısaltma miktarı tamamen ayak dolaşımı ile ilişkilidir. Tibia için defekt bölgesi $3 \mathrm{~cm}$ 'nin altında ise akut kısaltma yapılabilir, ancak $3 \mathrm{~cm}$ 'den uzun ise $2 \mathrm{~mm} /$ gün hızında kısaltmaya tedricen devam edilmelidir. Femurda ise defekt bölgesi $5 \mathrm{~cm}$ 'ye kadar akut olarak kısaltılabilmektedir. Kemiğin başka bir yerinden yapılacak osteotomi sonrası, çerçeve üzerindeki rodların yardımı ile distraksiyon osteogonezi yöntemi kullanılarak kemik boyu tedricen eşitlenir. Günlük uzatma miktarı distraksiyon osteogenezisi kuralları uygulanarak günde $1 \mathrm{~mm}(0,25 \mathrm{~mm} \times 4 \mathrm{kez})$ olarak yapılmalıdır.

Rezeksiyon sahası ameliyat öncesindeki röntgen ve MR görüntüleri ile belirlenir. Eksternal fiksatör çerçevesi akut kısaltma ve sonrasında kemiğin başka bir bölgesinden uzatmaya uygun şekilde oluşturulur. Öncelikle osteotomi yapilacak ve tedricen kemik boyunun uzatılacağı bölge belirlenir. Ardından belirlenen rezeksiyon sahasına uygun şekilde, genellikle transvers insizyon yapılarak kaynamayan bölge rezeke edilir. Akut kısaltma yapabilmek için fibuladan da uygun miktarda segment rezeksiyonu yapılır. Rezeksiyon sonrası oluşan boşluk akut olarak kısaltılarak K-teli ile geçici tespit yapılır. İnsizyonun kapatılması halka tespiti sonrası zor olacağından yara kapatılır. Ancak, enfekte olgularda iki aşamalı tedavi planlanır. Illk aşamada rezeksiyonu takiben kültürde üretilen mikroorganizmaya karşı veya geniş spektrumlu antibiyotik (teikoplanin, vankomisin vb.) emdirilmiş kemik çimentosu zincir halinde bölgeye konabilir. Klinik olarak bölgenin sağlıklı olduğu ve laboratuvar parametreleri (lökosit, CRP ve sedimentasyon) normale döndüğü görüldükten sonra ikinci aşamaya geçilebilir. Cerrahinin devamında ise halka proksimal ve distal referans telleri kullanılarak kemiğe adapte edilir. Skopi kontrolü sonrasında tüm halkalar ilgili segmentlere K-telleri ve Şanz vidaları ile tespit edilip stabil bir çerçeve elde edilir. Fibulanın proksimal ve distal bölümünden stabiliteyi arttırmak için zeytinli (olivli-stoplu) teller ile halkaya tespit edilir. Ardından gigli teli veya multipl drilleme tekniği ile osteotomi yapılarak stabilite kontrol edilir. Tüm bu işlemlerin ardından sistemin stabilitesi kontrol edilerek ameliyata son verilir. ${ }^{[5,18]}$

Cerrahi işlem sonrası birinci günde tedrici kompresyona başlanabilir. Uzatmaya ise 7-10 gün kadar sonra başlanmalıdır. Distraksiyon süresinde eklem hareketlerine hemen başlanmalı, kontraktürleri önlemek adına, hasta yoğun egzersiz yapmaya ve tolere edebildiği kadar yük vermeye cesaretlendirilmelidir.

Bu yöntemin uygulanmasının önemli dezavantajları arasında; akut kısaltma yapılabilmesi için intakt fibulanın rezeke edilme gereksinimi, akut kısaltma nedeniyle kasların kısalması ve buna bağlı kas zayıflıkları oluşması, bu kas zayıflıklarının giderilebilmesi için ciddi rehabilitasyon ihtiyacı ve akut kısaltma miktarının o bölgedeki kan dolaşımına bağlı olması sayılabilmektedir (Şekil 2).

\section{Kombine Teknik (Intramedüller Çiviyle Osteosentez ve Monolateral Fiksatörler Uzatma)}

Psödoartroza bağlı oluşan kemik kayıplarının rekonstrüksiyonunda kemik transportu ve akut kısaltma teknikleri tüm ortopedistler tarafindan kabul görmüş̧ olmakla birlikte, bu yöntemlerin özellikle "docking site" dediğimiz psödoartroz alanında kemik uçlarının geç karşılaşması, stabilite sorunu ve buna bağlı kaynamada gecikme gibi önemli bir dezavantajı bulunmaktadır. Bu sakıncayı önlemek adına; yaklaşık 10 yıldır daha stabil bir osteosentez yapabilmek için suprakondiller çivi kullanmaktayız. Bu sayede; akut kompresyon sonrası psödoartoz bölgesinde stabil bir osteosentez sağlanmış olur. Kemik kaybının $7 \mathrm{~cm}$ 'den büyük olduğu olgularda ise, monolateral fiksatörle bir yandan uzatma yaparken, diğer yandan docking site bölümüne tedrici kompresyon ( $2 \mathrm{~mm} /$ gün) yaparak kemik uçları karşıııkı hale getirilmiş olur. Daha sonra da çivinin proksimal vidaları kilitlenerek, osteosentez tamamlanmış olur. 

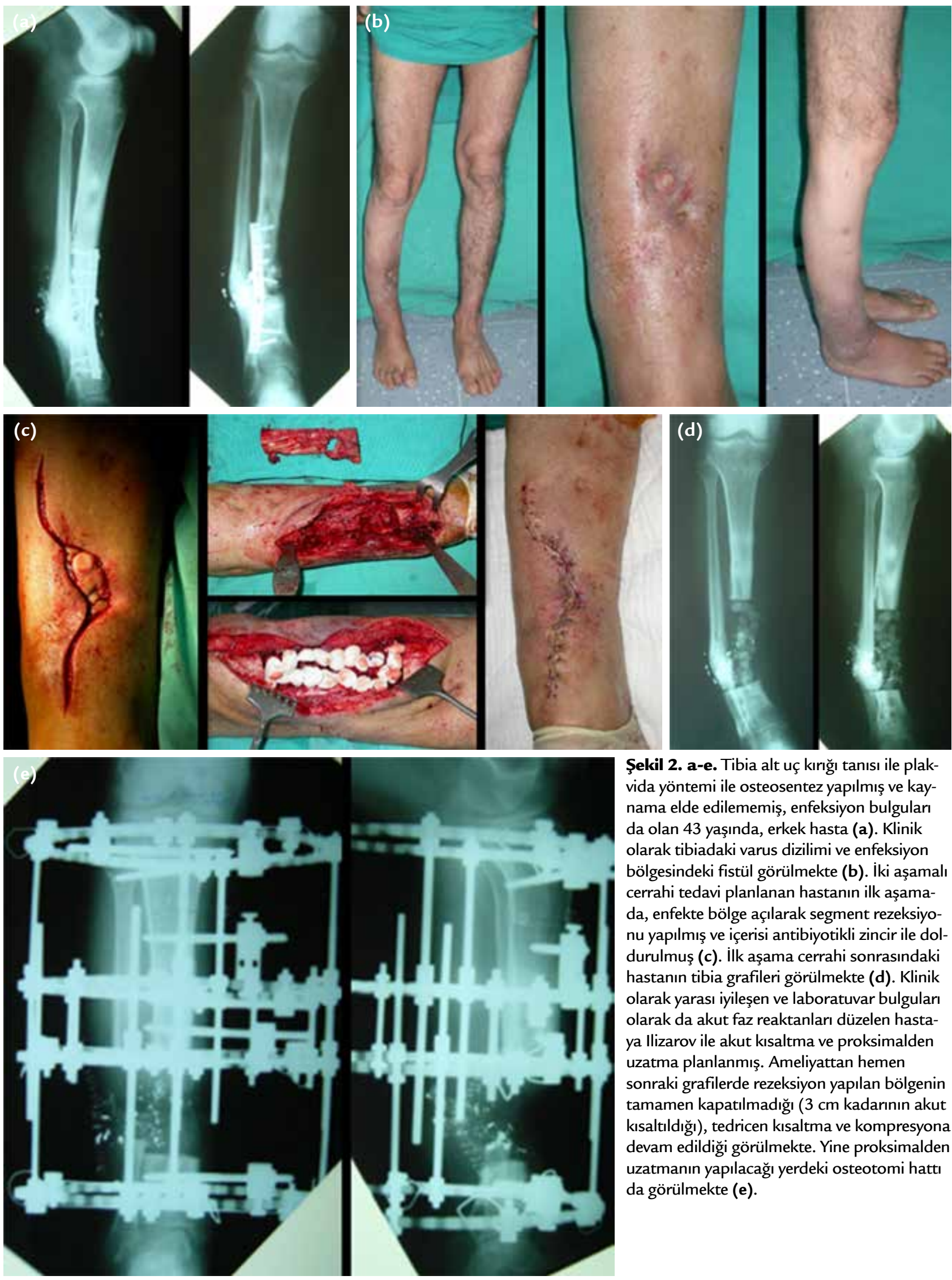

Şekil 2. a-e. Tibia alt uç kırığı tanısı ile plakvida yöntemi ile osteosentez yapılmış ve kaynama elde edilememiş, enfeksiyon bulguları da olan 43 yaşında, erkek hasta (a). Klinik olarak tibiadaki varus dizilimi ve enfeksiyon bölgesindeki fistül görülmekte (b). İki aşamalı cerrahi tedavi planlanan hastanın ilk aşamada, enfekte bölge açılarak segment rezeksiyonu yapılmış ve içerisi antibiyotikli zincir ile doldurulmuş (c). illk aşama cerrahi sonrasındaki hastanın tibia grafileri görülmekte (d). Klinik olarak yarası iyileşen ve laboratuvar bulguları olarak da akut faz reaktanları düzelen hastaya llizarov ile akut kısaltma ve proksimalden uzatma planlanmış. Ameliyattan hemen sonraki grafilerde rezeksiyon yapılan bölgenin tamamen kapatılmadığı $(3 \mathrm{~cm}$ kadarının akut kısaltıldığı), tedricen kısaltma ve kompresyona devam edildiği görülmekte. Yine proksimalden uzatmanın yapılacağı yerdeki osteotomi hattı da görülmekte (e). 

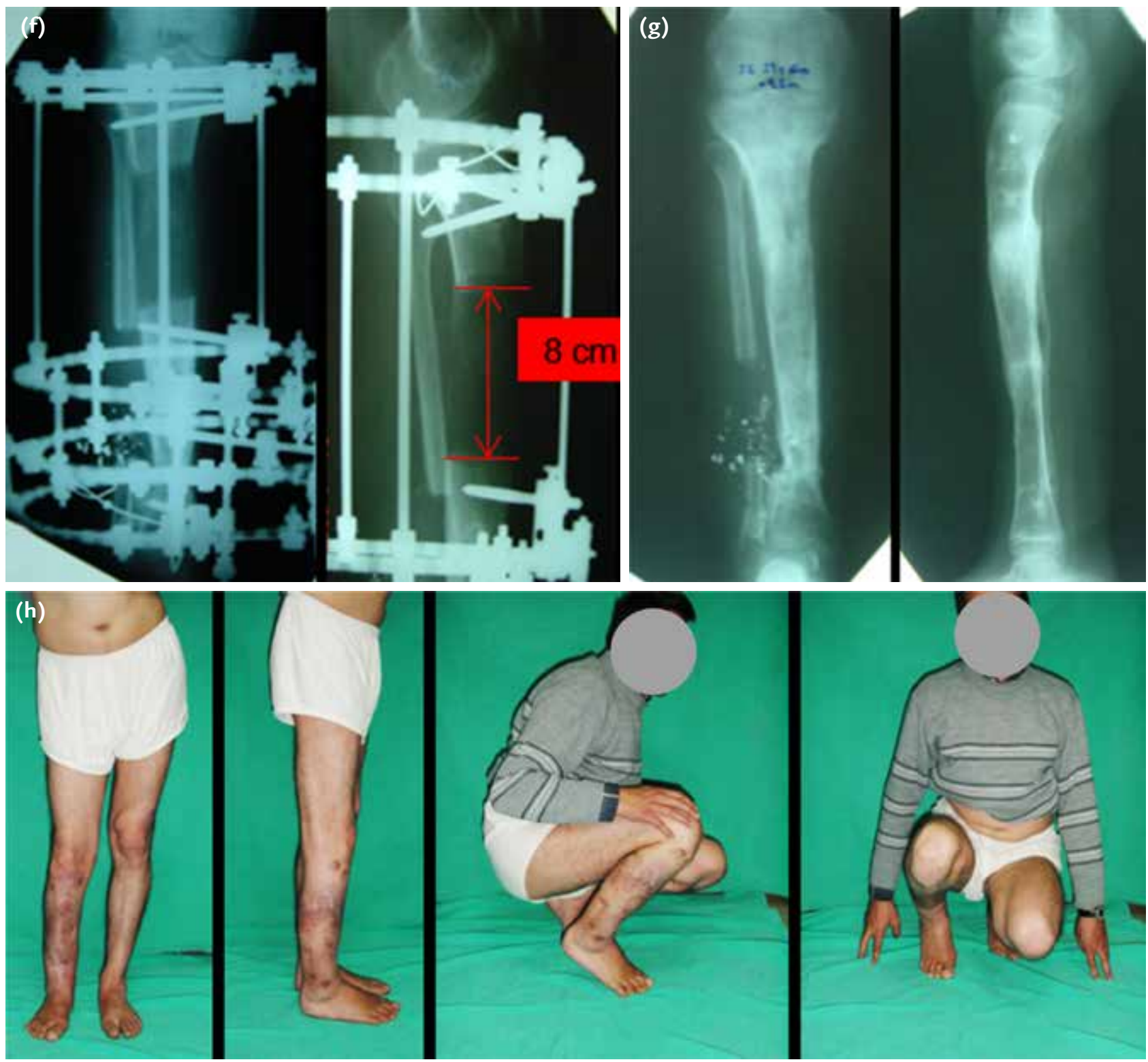

Şekil 2. f-h. Proksimalden uzatmanın yapıldığı ve $8 \mathrm{~cm}$ kadar distraksiyonun sağlandığı görülmekte (f). Ameliyattan bir yıl kadar sonra kompresyonun ve uzatmanın yapıldığı her iki sahanın da tamamen kaynadığı, tibiadaki deformitenin düzeldiği görülmekte (g). Ameliyattan bir yıl sonra hastanın klinik görüntüsü (h).

Bununla birlikte, bacak eşitsizliğini gidermek için, proksimal femurdan yaptığımız osteotomi sahasına distraksiyon osteogenezi prensiplerine uygun olarak uzatmaya devam edilir. Bacak eşitliği sağlandığında uzatmaya son verilip, konsolidasyon için beklenir. Üç kortekste kaynama görüldügünde fiksatör önce dinamize edilir, ardından anestezi altında çıkarılır (Şekil 3).

Çivi üzerinden uzatma tekniği ilk kez Dror Paley tarafından dünyaya tanıtılmış ve uzun yıllar ortopedistler tarafindan kullanılmıştır. ${ }^{[19]}$ Daha sonra Kocaoğlu ve ark. çivi üzerinden segment kaydırma tekniği ile oldukça başarılı sonuçlar bildirmişlerdir. Bu teknikle, enfekte femur psödoartrozlarında kaynamayla birlikte, hasta konforu yönünden oldukça önemli olan fiksatör taşıma süresini azaltmışlardır. Buna karşın, iki olguda enfeksiyonun pszöartroz alanından tüm femura yayılması gibi çok önemli bir komplikasyon olduğunu rapor etmişlerdir. Yine, Rozbruch ve ark. önce fiksatörle uzatma yapılıp, ardından intramedüller çivi yerleştirdikleri 

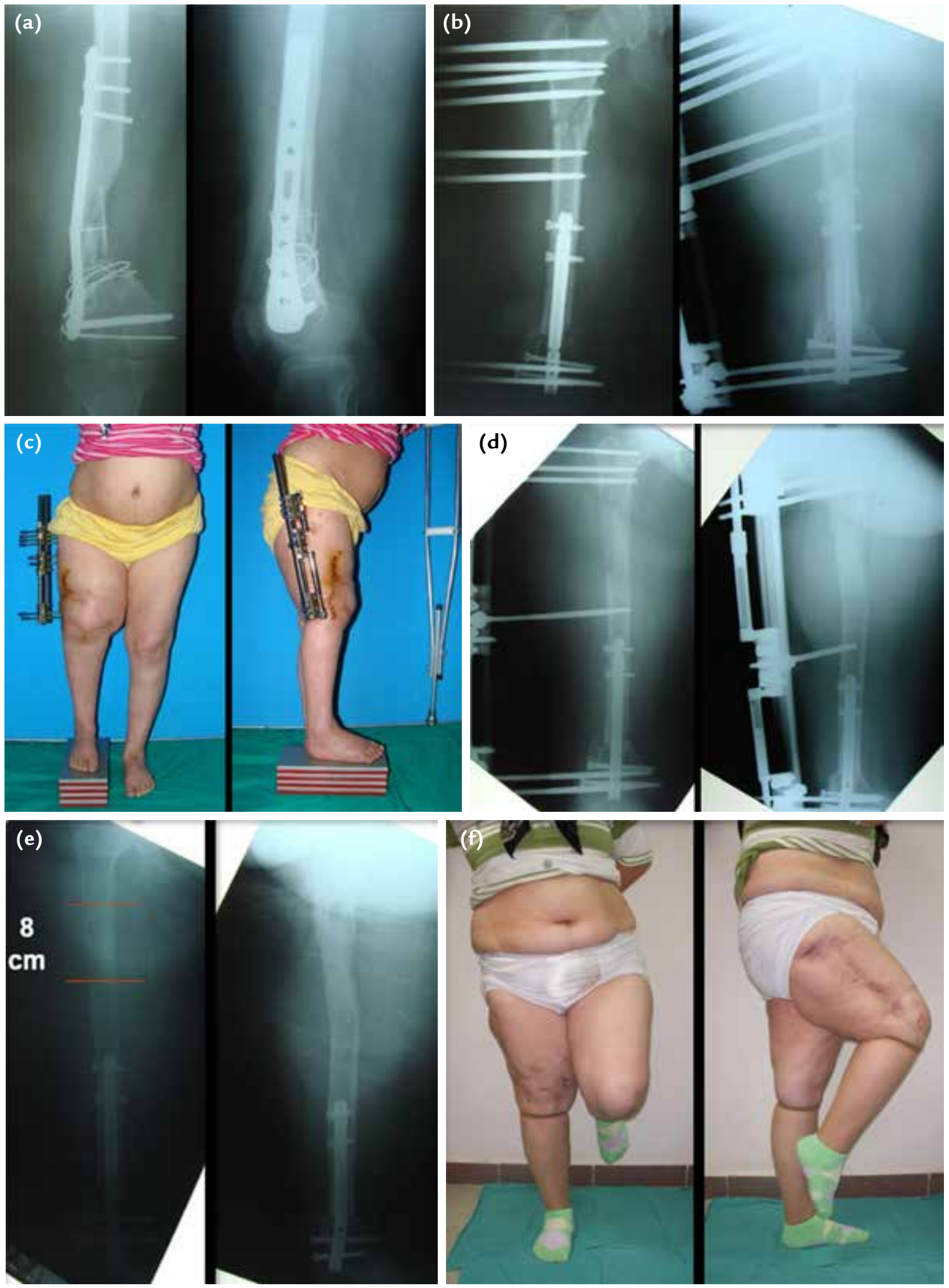

Şekil 3. a-f. Araç içi trafik kazası sonrasında sağ femur kırı̆ı̆ olan ve plak-vida ile tespiti yapılan, 43 yaşındaki kadın hastada 16 aylık tedavi sonucunda kaynama elde edilememiş (a). Hastaya kombine teknik uygulanarak; distal metafizer kaynamayan sahanın rezeksiyonu, akut kısaltarak intramedüller çivi ile tespit yapılmış. Aynı seansta var olan kısalığı gidermek için proksimalden osteotomi yapılarak uzatma planlanmış (b). Uzatma sorasındaki klinik görüntü (c). Hastada ameliyat sonrası altıncı ayda proksimalde $8 \mathrm{~cm}$ 'lik uzatma, distalde de kaynama elde edilmiş (d). Fiksatör çıkarıldıktan sonraki röntgen görüntüsü (e). Hastanın birinci yıl sonundaki klinik görüntüleri (f). 
çalışmalarında; enfeksiyonun yayılmasını önemli bir komplikasyon olarak bildirmişlerdir. ${ }^{[20]}$

Bizim 17 osteomiyelitli hastayı içeren ve rezeksiyon sonrasında, kombine teknik uyguladığımız çalışmamızda; ortalama 44 aylık takibin sonucunda tüm hastalarda kaynama gözlenirken, hiçbir hastada enfeksiyonun yayılması veya nüksüne rastlanmamıştır. Ayrıca, eksternal tespit süresi segment kaydırma serilerine göre daha kısa bulunurken, hastalarımızdaki fonksiyonel sonuçların oldukça tatminkar olduğu gözlenmiştir. ${ }^{[21]}$

Sonuç olarak; enfekte veya non-enfekte uzun kemik psödoartrozlarında, gerek enfeksiyonun eradike edilmesi gerekse ardından meydana gelen kemik kaybı ve uzuv eşitsizliğinin giderilmesinde; segment kaydırma, akut kısaltma - yeniden uzatma ve kombine tekniklerin üçünde de oldukça başarılı ve tatmin edici sonuçlar alınmaktadır. Ancak, hastaların iş durumu, hobileri, sosyokültürel özellikleri ve fiksatöre uyumları göz önüne alındığında; fiksatörle birlikte çivi kombinasyonlarının, hem fiksatör süresini kısaltma hem de hasta komforu ve psikolojisi açısından ön planda düşünülmesi gerektiği inancındayız.

\section{KAYNAKLAR}

1. DeCoster TA, Gehlert RJ, Mikola EA, Pirela-Cruz MA. Management of posttraumatic segmental bone defects. J Am Acad Orthop Surg 2004;12(1):28-38.

2. Leveny Eralp CS, Eren I. Reconstruction Techniques for Mega Bone Defects. In: Mehmet K, Tsuchiya H, Eralp L, editors. Advanced Techniques in Limb Reconstruction Surgery. New York: Springer; 2015. pp.159-76.

3. Walter G, Kemmerer M, Kappler C, Hoffmann R. Treatment algorithms for chronic osteomyelitis. Dtsch Arztebl Int 2012;109(14):257-64. Crossref

4. Cierny G 3rd, Mader JT. Approach to adult osteomyelitis. Orthop Rev 1987;16(4):259-70.

5. Sen C, Eralp L, Gunes T, Erdem M, Ozden VE, Kocaoglu M. An alternative method for the treatment of nonunion of the tibia with bone loss. J Bone Joint Surg Br 2006;88(6):783-9. Crossref

6. Cech O. Principles and technic of surgery for infected pseudarthrosis. Acta Chir Orthop Traumatol Cech 1970;37(2):88-95.

7. Paley D, Catagni MA, Argnani F, Villa A, Benedetti GB, Cattaneo R. Ilizarov treatment of tibial nonunions with bone loss. Clin Orthop Relat Res 1989;(241):146-65.
8. Khan MA, Jose RM, Taylor C, Ahmed W, Prinsloo D. Free radial forearm fasciocutaneous flap in the treatment of distal third tibial osteomyelitis. Ann Plast Surg 2012;68(1):58-61. Crossref

9. Masquelet AC, Begue T. The concept of induced membrane for reconstruction of long bone defects. Orthop Clin North Am 2010;41(1):27-37. Crossref

10. Gulsen M, Ozkan C. Angular shortening and delayed gradual distraction for the treatment of asymmetrical bone and soft tissue defects of tibia: a case series. J Trauma 2009;66(5):E616. Crossref

11. Kocaoglu M, EralpL, Rashid HU, Sen C, Bilsel K. Reconstruction of segmental bone defects due to chronic osteomyelitis with use of an external fixator and an intramedullary nail. J Bone Joint Surg Am 2006;88(10):2137-45. Crossref

12. Morris R, Hossain M, Evans A, Pallister I. Induced membrane technique for treating tibial defects gives mixed results. Bone Joint J 2017;99-B(5):680-5. Crossref

13. Tsang ST, Mills LA, Frantzias J, Baren JP, Keating JF, Simpson $\mathrm{AH}$. Exchange nailing for nonunion of diaphyseal fractures of the tibia: our results and an analysis of the risk factors for failure. Bone Joint J 2016;98-B(4):534-41. Crossref

14. van Niekerk $A H$, Birkholtz FF, de Lange $P$, Tetsworth $K$, Hohmann E. Circular external fixation and cemented PMMA spacers for the treatment of complex tibial fractures and infected nonunions with segmental bone loss. J Orthop Surg (Hong Kong) 2017;25(2):2309499017716242. Crossref

15. Gerber A, Gogolewski S. Reconstruction of large segmental defects in the sheep tibia using polylactide membranes. A clinical and radiographic report. Injury 2002;33 Suppl 2:B43-57.

16. Sen C, Kocaoglu M, Eralp L, Gulsen M, Cinar M. Bifocal compression-distraction in the acute treatment of grade III open tibia fractures with bone and soft-tissue loss: a report of 24 cases. J Orthop Trauma 2004;18(3):150-7.

17. Tetsworth K, Paley D, Sen C, Jaffe M, Maar DC, Glatt V, Hohmann E, Herzenberg JE. Bone transport versus acute shortening for the management of infected tibial non-unions with bone defects. Injury 2017;48(10):2276-84. Crossref

18. Paley D, Sen C, Tetsworth K. Acute shortening with subsequent relengthening versus bone transport in the treatment of tibial bone defect. In: 11th Asami North America Annual Scientific Meeting, February 18-25, Berkeley Ca, 2001.

19. Paley D, Herzenberg JE, Pareman G, Bhave A. Femoral lengthening over an intramedullary nail. A matched-case comparison with llizarov femoral lengthening. J Bone Joint Surg Am 1997;79(10):1464-80.

20. Rozbruch SR, Kleinman D, Fragomen AT, llizarov S. Limb lengthening and then insertion of an intramedulllary nail: a case-matched comparison. Clin Orthop Relat Res 2008;466(12):2922-32. Crossref

21. Sen C, Akgul T, Balci HI, Turgur N. Treatment of femoral bone defect following infection with combined technique. ILLRS Congress Miami 2015. Unpublished data. 